\title{
Efisiensi Dan Efektivitas Anggaran Belanja Pada Rumah Sakit Umum Daerah Cicalengka Kabupaten Bandung
}

\author{
${ }^{1}$ Yoga Pratama, ${ }^{2}$ Faizal Pikri \\ ${ }^{1}$ UIN Sunan Gunung Djati Bandung, Indonesia, Haiyogapratama@gmail.com \\ ${ }^{2}$ UIN Sunan Gunung Djati Bandung, Indonesia; faizalpikri@uinsgd.ac.id
}

\begin{abstract}
This journal discusses the efficiency and effectiveness of the budget for the Regional Public Service Agency with a case study at the Cicalengka Regional General Hospital in Kabupaten Bandung. Efficiency and effectiveness become a necessity for regional public service bodies because in their services they are required to provide optimal and best services without seeking certain benefits. This study aims to determine the realization of the budget of general hospitals in Bandung district cicalengka by analyzing the efficiency and effectiveness of the expenditure budget, as well as knowing the factors that cause the realization is not achieved optimally and know what are the obstacles in the implementation of the budget and efforts in solving problems on the realization of the budget. The results of the analysis show that the efficiency in the budget of general hospitals in Cicalengka is in the quite efficient category and the effectiveness analysis shows the results in the ineffective category due to the inadequate utilization and planning in optimizing the budget and the lack of available budget in meeting the needs of the hospital.
\end{abstract}

Keywords: Local Government, Efficiency, Effectiveness, Public Agency, Budgeting

\section{Pendahuluan}

Pengelolaan keuangan daerah menjadi acuan dalam tingkat kemajuan dan perkembangan daerah, melalui kebijakan otonomi daerah dan desentralisasi fiskal pemerintah daerah memiliki kewenangan dalam menggali pendapatan dan peran alokasi anggaran secara mandiri untuk menetapkan prioritas pembangunannya sehingga pengelolaan keuangan daerah apabila dilaksanakan dengan baik dan benar akan membuat aset serta keutuhan daerah tersebut terjaga (Kaunang \& Naukoko, 2016). Pemerintah daerah mempunyai hak otonomi untuk menentukan peraturan dan kebijakannya sendiri sesuai Peraturan Undang-Undang No. 23 Tahun 2014, Pemerintah Daerah diberi kewenangan menentukan Anggaran Pendapatan dan Belanja Daerah (APBD) sesuai dengan potensi dan kebutuhan dalam daerah, APBD dapat menjadi tolak ukur ataupun indikator kemampuan dalam membiayai atau melaksanakan berbagai tugas dan kegiatan serta rancangan proyek jangka menengah dalam periode waktu tertentu dengan tujuan penggunaan secara efisien dan efektif (Khusaini, 2018).

Adapun pengelolaan keuangan daerah dapat diartikan sebagai hak dan kewajiban yang dapat dinilai dengan uang demikian pula segala sesuatu baik berupa uang maupun barang yang dapat dijadikan kekayaan daerah sepanjang belum dimiliki oleh negara atau daerah yang lebih tinggi serta pihak-pihak lain sesuai peraturan perundangan yang berlaku (Halim, 2012) selanjutnya (Khusaini, 2018) mengatakan bahwa pengelolaan keuangan daerah dapat diartikan juga sebagai keseluruhan kegiatan yang meliputi perencanaan, penatausahaan, pelaporan, pertanggung jawaban dan pengawasan daerah.

Berbicara mengenai laporan pertanggungjawaban keuangan tentunya berhubungan dengan keterbukaan informasi publik hal ini berdasarkan penelitian (Umam \& Ariyoso, 2019) tentang pengelolaan pelayanan informasi publik pada kinerja manajemen kementrian sekretariat negara, bahwa masyarakat berhak untuk mendapatkan akses pelayanan publik yang berkualitas, berprosedur jelas, dilaksanakan dengan segera, dengan biaya yang pantas, dan 
dengan mengedapankan dari waktu ke waktu. Hal ini berkembang seiring dengan kesadaran bahwa dalam berkehidupan negara yang demokratis memiliki hak untuk dilayani, serta badan publik berkewajiban untuk menyediakan informasi secara efektif dan efisien. Maka Rumah Sakit Umum Daerah Cicalengka Kabupaten Bandung dalam menyediakan informasi publik dengan melakukan publikasi pada laman resmi sehingga dapat dilihat dan dinilai oleh masyarakat.

Badan Layanan Umum Daerah (BLUD) merupakan bagian dari perangkat Pemerintah Daerah, BLUD diterapkan oleh Satuan Kerja Perangkat Daerah (SKPD) atau unit satuan kerja perangkat daerah untuk memberikan pelayanan kepada masyarakat dengan memiliki keistimewaan yaitu dapat mengelola keuangannya secara fleksibel sebagai pengecualian pengelolaan keuangan dengan SKPD lainnya. Rumah Sakit Umum Daerah Cicalengka Kabupaten Bandung merupakan SKPD yang ditunjuk oleh Pemerintah Daerah Kabupaten Bandung untuk menerapkan pola pengelolaan keuangan dengan sistem BLUD sesuai dengan keputusan Bupati Kabupaten Bandung No.445/Kep.587-Org/2013. Sebagaimana tercantum pada Pasal 48 Ayat 1 UU No. 44 Tahun 2009 tentang Sumber-Sumber Pendapatan dan Biaya Rumah Sakit maka RSUD Cicalengka diberikan kewenangan dalam mengelola keuangannya.

Pengelolaan keuangan pada Rumah Sakit Umum Daerah Cicalengka Kabupaten Bandung sebagai BLUD tentunya harus mengutamakan prinsip efisiensi dan efektivitas sehingga anggaran belanja yang disediakan dapat terealisasi secara baik, namun kenyataannya berdasarkan data yang dilihat dari Laporan Realisasi Anggaran (LRA) RSUD Cicalengka Tahun anggaran 2015-2018 (https://rsudcicalengka.bandungkab.go.id) menunjukan realisasi yang tidak tercapai dari anggaran yang disediakan, berikut ini sajian data realisasi anggaran:

Tabel. 1

Laporan Realisasi Anggaran Belanja RSUD Cicalengka Tahun 2015-2018

\begin{tabular}{|c|c|c|c|c|}
\hline \multirow[t]{2}{*}{ Tahun } & \multicolumn{3}{|c|}{ Belanja } & \multirow[t]{2}{*}{$\%$} \\
\hline & Target & Realisasi & Selisih & \\
\hline 1 & 2 & 3 & 4 & $\begin{array}{c}4=3 / \\
2\end{array}$ \\
\hline 2015 & 60.464 .803 .349 & 40.291 .210 .289 & 20.173 .593 .060 & 66.64 \\
\hline 2016 & 57.938 .814 .108 & 47.008 .160 .261 & 10.930 .653 .847 & 81.13 \\
\hline 2017 & 58.678 .853 .252 & 44.199 .941 .446 & 14.478 .911 .806 & 73.11 \\
\hline 2018 & 67.989 .176 .411 & 54.612 .505 .791 & 13.376 .670 .620 & 80.33 \\
\hline
\end{tabular}

Sumber: Ikhtisar Laporan Keuangan RSUD Cicalengka, 2020

Melihat sajian laporan Realisasi anggaran Rumah Sakit Umum Daerah (RSUD) Cicalengka tahun 2015-2018, Target pada tahun 2015 adalah Rp.60.464.803.349,- dengan realisasi Rp.40.291.210.289,- adapun selisih diantara keduanya Rp20.173.593.060,berikutnya pada tahun 2016 Target anggaran adalah Rp60.464.803.349,- dengan realisasi Rp40.291.210.289,- adapun selisih diantara keduanya adalah Rp.10.930.653.847,- berikutnya pada tahun 2017 Target yang direncanakan adalah Rp.58.678.853.252,- dengan realisasi sebesar Rp.44.199.941.446,- dengan selisih diantara keduanya Rp.14.478.911.806,- berikutnya pada tahun 2018 Target anggaran yang direncanakan adalah Rp.67.989.176.411,- dengan realisasi Rp.54.612.505.791 dengan selisih diantara keduanya sebesar Rp.13.376.670.620,-Apabila disajikan presentase terhadap selisih keseluruhan antara target belanja dan realisasi 
belanja maka diperoleh hasil presentase pada tahun 2015 66.64\%, tahun $201681.13 \%$, tahun 2017 73.11\%, dan tahun 2018 80.33\%. Agar lebih jelas dalam mengetahui tingkat capaian realisasi anggaran belanja maka dapat dilihat dari grafik berikut:

Gambar. 1

\section{Grafik Realisasi Anggaran Belanja RSUD Cicalengka Tahun 2015-2018}

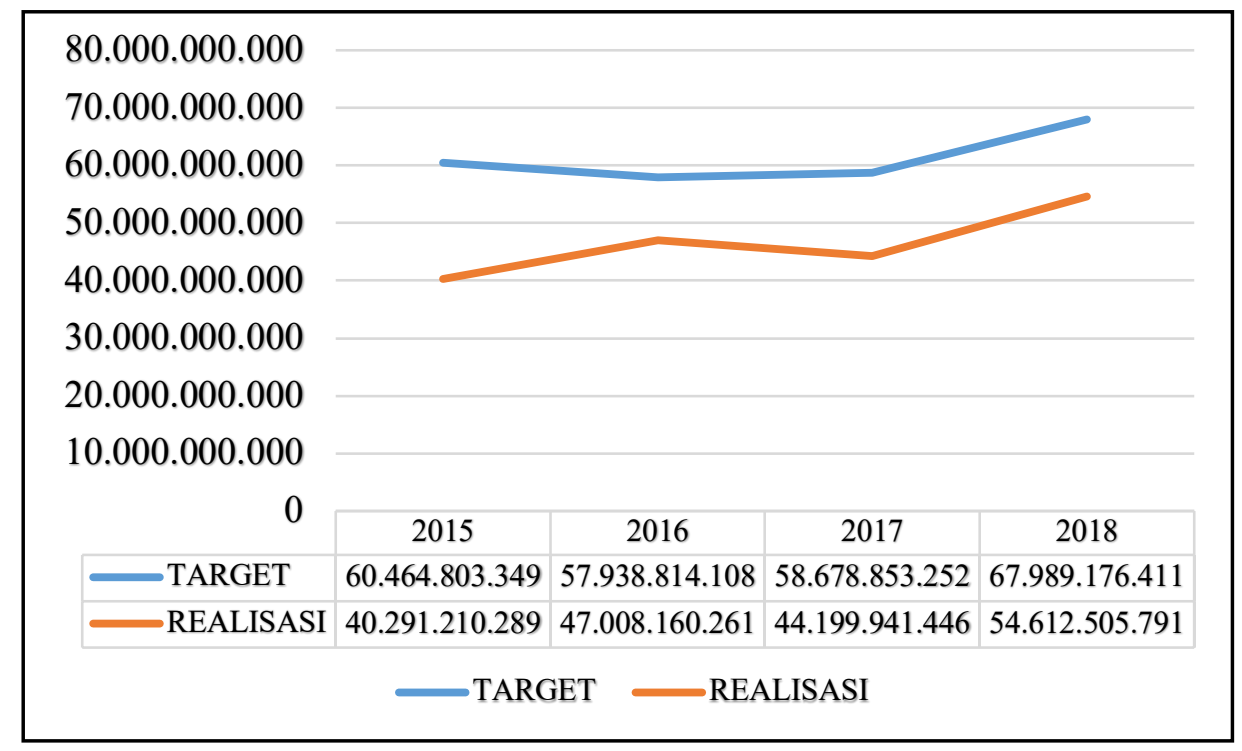

Sumber: Diolah oleh penulis (2020)

Dilihat dari grafik realisasi anggaran belanja diatas, diketahui bahwa capaian realisasi anggaran belanja tidak mendekati dari target anggaran belanja karena grafik realisasi tidak menunjukan kesimbangan dengan grafik target anggaran belanja, bila dilihat pada tahun 2015 target anggaran belanja adalah Rp.60.464.803.349,- lalu mengalami penurunan pada tahun 2016 sebesar Rp.57.938.814.108,- lalu berikutnya tahun 2017 target anggaran belanja naik namun tidak terlalu signifikan sebesar Rp.58.678.853.252,- lalu pada tahun 2018 naik dengan sangat signifikan sebesar Rp.67.989.176.411,- bila melihat realisasi anggaran anggaran belanjanya dari tahun 2015-2018 terlihat bahwa secara keseluruhan capaiannya tidak mendekati target anggaran, dilihat pada tahun 2015 realisasinya adalah Rp.40.291.210.289,lalu pada tahun 2016 capaian realisasi tinggi dari tahun sebelumnya sebesar Rp.47.008.160.261,- lalu berikutnya pada tahun 2017 capaian realisasi belanja kembali turun sebesar Rp.44.199.941.446,- dan pada tahun 2018 capaian realisasi belanja naik secara signifikan sebesar Rp.54.612.505.791,- .

Dalam Penyerapan anggaran belanja yang disediakan oleh pemerintah daerah akan memberikan dua aspek, pertama bisa menunjukkan adanya efisiensi anggaran dan kedua jika terjadi selisih kurang maka akan terjadi kelemahan dalam perencanaan anggaran belanja yang kurang tepat, atau tidak terserapnya anggaran tersebut karena ada program dan kegiatan yang tidak dilaksanakan sehingga tidak efektif, apabila penyerapan anggaran kurang dari 95\%, berdasarkan Peraturan Menteri Keuangan Nomor 258 Tahun 2015 tentang Tata Cara Pemberian Penghargaan dan Pengenaan Sanksi atas Pelaksanaan Anggaran Belanja Kementrian/Lembaga, maka satuan kerja yang bersangkutan akan diberikan sanksi. Merujuk pada Permendagri No. 79 Tahun 2018, BLUD harus mengelola pelayanan secara efisen dan efektif kepada masyarakat dan dimaksudkan tanpa mencari keuntungan tertentu, maka perlu dilanjutkan dengan mengukur analisis efisiensi dan efektifitas anggaran belanja agar dapat diketahui faktor apa saja yang menjadi penghambat dan kendala pada pelaksanaan realisasi anggaran belanja pada Rumah Sakit Umum Daerah Cicalengka Kabupaten Bandung. 
Anggaran dijelaskan oleh (Mahsun, 2014) merupakan perencanaan keuangan pada masa yang akan datang mencakup jangka waktu dalam periode satu tahun serta dinyatakan dalam satuan moneter, berikutnya anggaran digunakan sebagai perencanaan dalam jangka pendek organisasi yang diterjemahkan ke dalam berbagai aspek program pada rencana keuangan tahunan. Ditinjau pada anggaran daerah maka (Shah, 2007) menjelaskan bahwa pengalokasian anggaran daerah merefleksikan dari tradisi,institusi,serta kapasitas yang ada pada daerah tersebut serta menilai kualitas anggaran dengan melihat efisiensi dan efektivitas mengelola anggaran. Anggaran sebagai salah satu alat bantu manajemen karena dalam peranannya dapat merencanakan, mengatur, dan mengevaluasi jalannya suatu kebijakan (Nafarin, 2012)

Belanja daerah merupakan semua pengeluaran yang terdapat pada rekenening kas umum daerah untuk mengurangi ekuitas dana lancar terhadap periode anggaran daerah serta tidak akan memperoleh pembayaranya kembali oleh pemerintah daerah (Ayuningtyas, 2014). Ketentuan Pasal 298 UU No.23 Tahun 2014 bahwa belanja daerah diprioritaskan dalam mendanai urusan pemerintahan wajib terkait pelayanan dasar dengan standar pelayanan minimal serta berpedoman kepada standar teknis regional sesuai ketentuan perundangundangan, sementara belanja daerah yang menjadi urusan tidak wajib terkait pelayanan dasar berpedoman pada analisis standar belanja dan harga satuan regional.

Efisiensi merupakan hubungan antara output berupa barang atau jasa yang dihasilkan dengan sumber daya yang digunakan untuk menghasilkan output tersebut. Secara sistematis, efisiensi merupakan perbandingan antara output dengan input atau dengan istilah lain output per unit input. Konsep efisiensi hampir sama dengan produktivitas suatu organisasi program, atau kegiatan dikatakan efisien apabila mampu menghasilkan output sebesar-besarnya. Efisiensi berarti pembelanjaan anggaran secara cermat (spending well) (Mahmudi, 2019)

Efektivitas merupakan perbandingan antara hasil yang diharapkan (target) dengan hasil yang sesungguhnya dicapai. Hasil atau target yang diharapkan merupakan outcome sedangkan hasil yang dicapai merupakan output. Efektivitas membandingkan antara outcome dengan output suatu organisasi, program, atau kegiatan dinilai efektif apabila output yang dihasilkan bisa memenuhi tujuan yang diharapkan atau dengan kata lain anggaran digunakan secara tepat (Mahmudi, 2019)

Penelitian ini bertujuan untuk mengetahui efisiensi dan efektivitas anggaran belanja pada Rumah Sakit Umum Daerah Cicalengka Kabupaten Bandung sebagai SKPD yang berstatus BLUD, dengan merealisasikan anggaran secara efisien dan efektif tentunya proses penganggaran nya pun akan baik dan optimal namun jika ditemukan selisih kurang ataupun realisasi yang tidak tercapai maka perlu dilakukan penelitian dengan analisis efisiensi dan efektivitas anggaran belanja pada RSUD Cicalengka.

\section{Metode Penelitian}

Dalam melakukan penelitian digunakan metode yang sesuai agar penelitian yang dilaksanakan sesuai dan tepat untuk menyelesaikan pemecahan masalah, metode penelitian yang digunakan menggunakan deskriptif dengan pendekatan kualitatif. Penelitian deskriptif disebut sebagai penelitian yang menghasilkan data deskriptif berupa data-data tertulis atau lisan dari perilaku yang diamati secara berkembang, alamiah dan dinamis. Pendekatan deskripftif merupakan pendekatan yang menggambarkan atau menganalisis hasil penelitian tetapi tidak digunakan dalam membuat kesimpulan yang lebih luas (Sugiyono, 2013). Penelitian deskriptif dengan pendekatan kualitatif digunakan dalam penelitian ini karena relevan dengan permasalahan yang dikaji karena bersifat menjelaskan atau mendeskripsikan secara mendalam 
dengan sasaran penelitian yang dikaji yaitu anggaran belanja pada Rumah Sakit Umum Daerah (RSUD) Cicalengka dan dalam penelitian ini tidak bertujuan untuk mencari hubungan,pengaruh, atau membandingkan antar variabel.

Penelitian diawali dengan pengukuran efisiensi dan efektivitas realisasi anggaran belanja. Teknik pengumpulan data didapat dari hasil observasi penelitian yaitu Laporan Realisasi Anggaran (LRA) RSUD Cicalengka Tahun 2015-2018 serta dokumen pendukung berupa Laporan Kinerja Instasi Pemerintahan (LAKIP) serta Catatan atas Laporan Keuangan (CaLK) yang didapat pada ikhtisar laporan keuangan RSUD Cicalengka dan data penunjang lain yang didapatkan pada laman resmi RSUD Cicalengka. Selanjutnya dalam membahas hasil analisis pengukuran efisiensi dan efektivitas maka dilakukan observasi wawancara dengan informan atau narasumber menggunakan teknik purposive yaitu penentuan informan dipilih berdasarkan kriteria yang relevan dengan bahasan penelitian, Informan yang dipilih dalam penelitian ini pada bidang keuangan RSUD Cicalengka meliputi: 1) Kabag. Mobilisasi Dana 2) Kabag. Bendahara Penerimaan 3) Kabag. Bendahara Pengeluaran 4) Kasubbag Program dan Kehumasan 5) Unit Pelaksanaan Akuntansi dan Pelaporan Keuangan.

Teknik analisis data dilakukan dengan pengukuran efisiensi terlebih dahulu, menurut (Mahmudi, 2019) efisiensi dapat diukur dengan membandingkat output dengan input dalam anggaran belanja pengukuran efisiensi dilakukan dengan mebandingkan Realisasi belanja langsung dan realisasi anggaran belanja, maka rumus yang digunakan dalah sebagai berikut:

$$
\text { Efisiensi }=\frac{\text { Realisasi Anggaran Belanja Langsung }}{\text { Realisasi Anggaran Belanja }} \times 100 \%
$$

Dengan merujuk kriteria Efisiensi sesuai dengan keputusan Kementrian Dalam Negeri Nomor 690. 900-327 Tahun 1996, kriteria tingkat efisiensi dapat dilihat pada tabel berikut:

Tabel. 2

Kriteria Efisiensi Anggaran Belanja

\begin{tabular}{ll}
\hline Persentase Pengukuran & Kriteri Efisiensi \\
\hline $100 \%$ Keatas & Tidak Efisien \\
\hline $90 \%$ sampai $100 \%$ & Kurang Efisien \\
\hline $80 \%$ sampai $90 \%$ & Cukup Efisien \\
\hline $60 \%$ sampai $80 \%$ & Efisien \\
\hline Kurang dari $60 \%$ & Sangat Efisien
\end{tabular}

Sumber: Kementrian Dalam Negeri Nomor 690. 900-327 Tahun 1996

Berikutnya pengukuran efektivitas menurut (Mahmudi, 2019) dapat diukur dengan membandingkan outcome dengan output dalam anggaran belanja pengukuran efektivitas dilakukan dengan membandingkan realisasi anggaran belanja dengan target anggaran belanja, maka rumus yang digunakan adalah sebagai berikut:

$$
\text { Efektivitas }=\frac{\text { Realisasi Anggaran Belanja }}{\text { Anggaran Belanja }} \times 100 \%
$$


Dengan merujuk kriteria Efisiensi sesuai dengan keputusan Kementrian Dalam Negeri Nomor 690. 900-327 Tahun 1996, kriteria tingkat efektivitas dapat dilihat pada tabel berikut:

Tabel. 3

\begin{tabular}{ll}
\multicolumn{2}{c}{ Kriteria Efektivitas Anggaran Belanja } \\
\hline Persentase Pengukuran & Kriteri Efisiensi \\
\hline $100 \%$ Keatas & Sangat Efektif \\
\hline $90 \%$ sampai $100 \%$ & Efektif \\
\hline $80 \%$ sampai $90 \%$ & Cukup Efisien \\
\hline $60 \%$ sampai $80 \%$ & Kurang Efektif \\
\hline Kurang dari 60\% & Tidak Efektif \\
\hline Sumber: Kementerian Dalam Negeri Nomor 690. 900-327 Tahun 1996
\end{tabular}

Selanjutnya pembahasan dalam analisis efisiensi dan efektivitas anggaran belanja pada hasil observasi wawancara bersama informan digunakan teknik Miles dan Huberman (1984) maka tahapan analisis model Miles dan Huberman adalah 1) Reduksi data 2) Penyajian data 3) Penarikan kesimpulan.

\section{Hasil dan Pembahasan}

1. Hasil analisis pengukuran efisiensi anggaran belanja

Pada pengukuran efisiensi diawali dengan menyajikan Laporan Realisasi Anggaran Belanja dan Realisasi Belanja langsung, berdasarkan pengukuran efisiensi menurut (Mahmudi, 2019) dengan membandingkan output dan input maka dalam efisiensi anggaran belanja dengan cara membandingkan Realisasi Belanja dan Realisasi Belanja Langsung, berikut adalah adalah sajian hasil pengukuran efisiensi:

Tabel. 4

\section{Laporan Realisasi Belanja dan Realisasi Belanja Langsung RSUD Cicalengka}

\begin{tabular}{clc}
\hline Tahun & Realisasi Belanja & Realisasi Belanja Langsung \\
\hline 2015 & Rp.40.291.210.289,- & Rp.33.117.530.009,- \\
\hline 2016 & Rp.47.008.160.261,- & Rp.39.355.161.332,-- \\
\hline 2017 & Rp.44.199.941.446,-- & Rp.36.272.364.685,-- \\
\hline 2018 & Rp.54.612.505.791,- & Rp.46.025.895.602,- \\
\hline
\end{tabular}

Sumber: LRA RSUD Cicalengka (2020)

Melalui tabel diatas maka pengukuran efisiesnsi dilaksanakan sebagai berikut:

a. Tahun 2015

Hasil pengukuran efisiensi anggaran belanja, Rumah Sakit Umum Daerah Cicalengka Kabubapten Bandung tahun 2015:

$$
\frac{\text { Rp. } 33.117 .530 .009}{\text { Rp. } 40.291 .210 .289} \times 100 \%=82.19 \% \text { Cukup Efisien }
$$


Hasil perhitungan efisiensi anggaran belanja Rumah Sakit Umum Daerah Cicalengka Kabupaten Bandung tahun 2015, hasil pengukuran adalah 82.19\%.

b. Tahun 2016

Berikut hasil pengukuran efisiensi anggaran belanja, Rumah Sakit Umum Daerah Cicalengka Kabupaten Bandung tahun 2016:

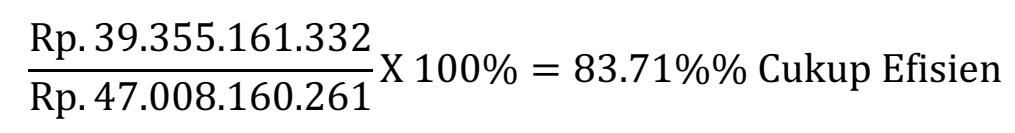

Hasil perhitungan efisiensi anggaran belanja Rumah Sakit Umum Daerah Cicalengka Kabupaten Bandung tahun 2016, hasil pengukuran adalah 83.71\%.

c. Tahun 2017

Berikut hasil pengukuran efisiensi anggaran belanja, Rumah Sakit Umum Daerah Cicalengka Kabupaten Bandung tahun 2017:

$$
\frac{\text { Rp. } 36.272 .364 .685}{\text { Rp. } 44.199 .941 .446} \text { X 100\% }=82.06 \% \text { Cukup Efisien }
$$

Hasil perhitungan efisiensi anggaran belanja Rumah Sakit Umum Daerah Cicalengka Kabupaten Bandung tahun 2017, hasil pengukuran nya adalah $82.06 \%$.

d. Tahun 2018

Berikut hasil pengukuran efisiensi anggaran belanja, Rumah Sakit Umum Daerah Cicalengka Kabupaten Bandung tahun 2018:

$$
\frac{\text { Rp. } 46.025 .895 .602}{\text { Rp. } 54.612 .505 .791} \text { X 100\% }=84.27 \% \text { Cukup Efisien }
$$

Hasil perhitungan efisiensi anggaran belanja Rumah Sakit Umum Daerah Cicalengka Kabupaten Bandung tahun 2018, hasil pengukuran nya adalah $84.27 \%$.

Berdasarkan hasil analisis diatas maka efisiensi anggaran belanja RSUD Cicalengka Tahun Anggaran 2015-2018 menurut kriteria keputusan Kementrian Dalam Negeri Nomor 690. 900-327 Tahun 1996 adalah sebagai berikut:

Tabel. 5

\section{Kriteria Efisiensi Anggaran Belanja RSUD Cicalengka}

\begin{tabular}{lll}
\hline Tahun & Efisiensi & Kriteria \\
\hline 2015 & $82.19 \%$ & Cukup efisien \\
\hline 2016 & $83.71 \%$ & Cukup efisien \\
\hline 2017 & $82.06 \%$ & Cukup efisien \\
\hline 2018 & $84.27 \%$ & Cukup efisien \\
\hline
\end{tabular}

Sumber: Diolah peneliti (2020) 
Kesimpulan dari hasil analisis pengukuran efisiensi anggaran belanja RSUD Cicalengka ditinjau secara keseluruhan dari tahun 2015-2018 maka dapat dikatakan cukup efisien dengan kecenderungan stabil setiap tahunnya, berikut sajian hasil pengukuran dalam bentuk grafik:

\section{Gambar. 2}

\section{Efisiensi Anggaran Belanja}

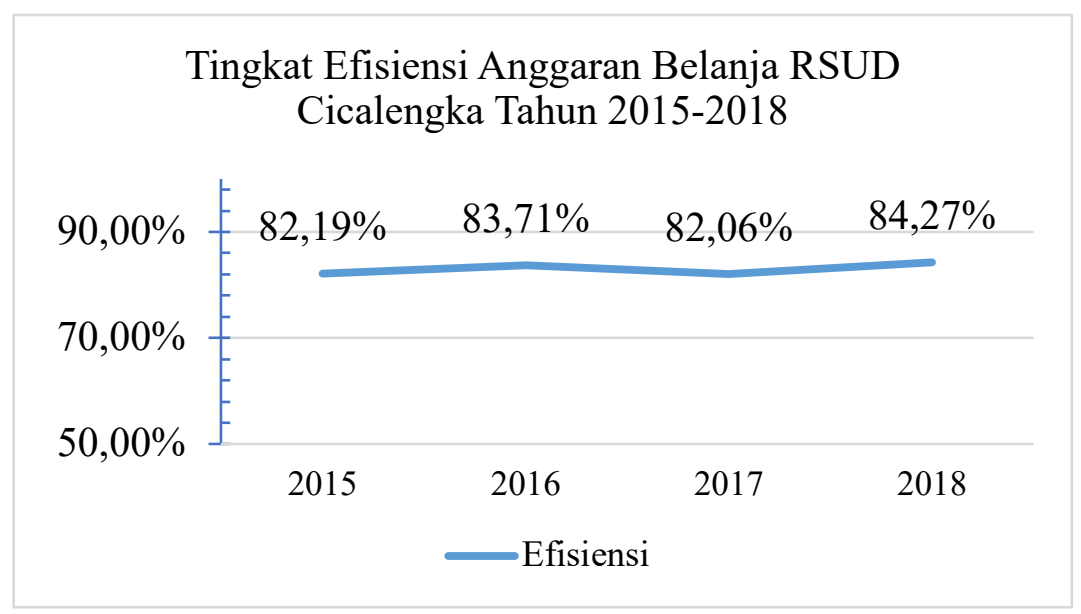

Sumber: Diolah peneliti (2020)

2. Hasil Pengukuran Efektivitas Anggaran Belanja

Pada pengukuran efektivitas diawali dengan menyajikan Laporan Realisasi Anggaran Belanja dan Realisasi Belanja langsung, berdasarkan pengukuran efisiensi menurut (Mahmudi, 2019) dengan membandingkan outcome dan output maka dalam efektivitas anggaran belanja dengan cara membandingkan Target Anggaran Belanja dan Realisasi Anggaran Belanja, berikut adalah adalah sajian hasil pengukuran efektivitas:

Tabel. 6

Laporan Realisasi Belanja dan Realisasi Belanja Langsung RSUD Cicalengka

\begin{tabular}{ccc}
\hline Tahun & Target Anggaran Belanja & Realisasi Anggaran Belanja \\
\hline 2015 & Rp.60.464.803.349,- & Rp.40.291.210.289,- \\
\hline 2016 & Rp.57.938.814.108,- & Rp.47.008.160.261,- \\
\hline 2017 & Rp.58.678.853.252,- & Rp.44.199.941.446,- \\
\hline 2018 & Rp.67.989.176.411,- & Rp.54.612.505.791,- \\
\hline
\end{tabular}

Sumber: LRA RSUD Cicalengka (2020)

Melalui tabel diatas maka pengukuran efisiesnsi dilaksanakan sebagai berikut:

a. Tahun 2015

Hasil pengukuran efektivitas anggaran belanja, Rumah Sakit Umum Daerah Cicalengka Kabupaten Bandung tahun 2015:

$$
\frac{\text { Rp. } 40.291 .210 .289}{\text { Rp. } 60.464 .803 .349} \text { X 100\% }=66.64 \% \text { kurang Efektif }
$$


Berdasarkan hasil perhitungan efektivitas anggaran belanja Rumah Sakit Umum Daerah Cicalengka Kabupaten Bandung tahun 2015, hasil pengukuran adalah 66.64\%.

b. Tahun 2016

Hasil pengukuran efektivitas anggaran belanja, Rumah Sakit Umum Daerah Cicalengka Kabupaten Bandung tahun 2016:

$$
\frac{\text { Rp. } 47.008 .160 .261}{\text { Rp. 57.938.814.108 }} \text { X 100\% }=81.13 \% \text { Cukup Efektif }
$$

Berdasarkan hasil perhitungan efektivitas anggaran belanja Rumah Sakit Umum Daerah Cicalengka Kabupaten Bandung tahun 2016, hasil pengukuran yang dilakukan oleh penulis adalah $81.13 \%$.

c. Tahun 2017

Hasil pengukuran efektivitas anggaran belanja, Rumah Sakit Umum Daerah Cicalengka Kabupaten Bandung tahun 2017:

$$
\frac{\text { Rp. } 44.199 .941 .446}{\text { Rp. } 58.678 .853 .252} \text { X } 100 \%=73.11 \% \text { Kurang Efektif }
$$

Berdasarkan hasil perhitungan efektivitas anggaran belanja Rumah Sakit Umum Daerah Cicalengka Kabupaten Bandung tahun 2017, hasil pengukuran yang dilakukan oleh penulis adalah $73.11 \%$.

d. Tahun 2018

Hasil pengukuran efektivitas anggaran belanja, Rumah Sakit Umum Daerah Cicalengka Kabupaten Bandung tahun 2017:

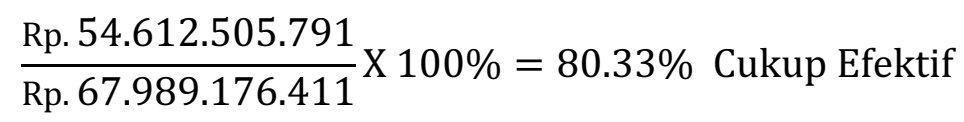

Berdasarkan hasil perhitungan efektivitas anggaran belanja Rumah Sakit Umum Daerah Cicalengka Kabupaten Bandung tahun 2018, hasil pengukuran yang dilakukan oleh penulis adalah $80.33 \%$.

Berdasarkan hasil analisis diatas maka efektivitas anggaran belanja RSUD Cicalengka Tahun Anggaran 2015-2018 menurut kriteria keputusan Kementrian Dalam Negeri Nomor 690. 900-327 Tahun 1996 adalah sebagai berikut:

Tabel. 5

Kriteria Efisiensi Anggaran Belanja RSUD Cicalengka

\begin{tabular}{lll}
\hline Tahun & Efektivitas & Kriteria \\
\hline 2015 & $66.64 \%$ & Kurang Efektif \\
\hline 2016 & $81.13 \%$ & Cukup Efektif \\
\hline 2017 & $72.11 \%$ & Kurang Efektif \\
\hline 2018 & $80.33 \%$ & Cukup Efektif \\
\hline
\end{tabular}


Kesimpulan dari hasil analisis pengukuran efektivitas anggaran belanja RSUD Cicalengka ditinjau secara keseluruhan dari tahun 2015-2018 maka dapat dikatakan kurang efektif dengan fluktuasi naik turun setiap tahunnya, berikut sajian hasil pengukuran dalam bentuk grafik:

Gambar. 3

Efektivitas Anggaran Belanja

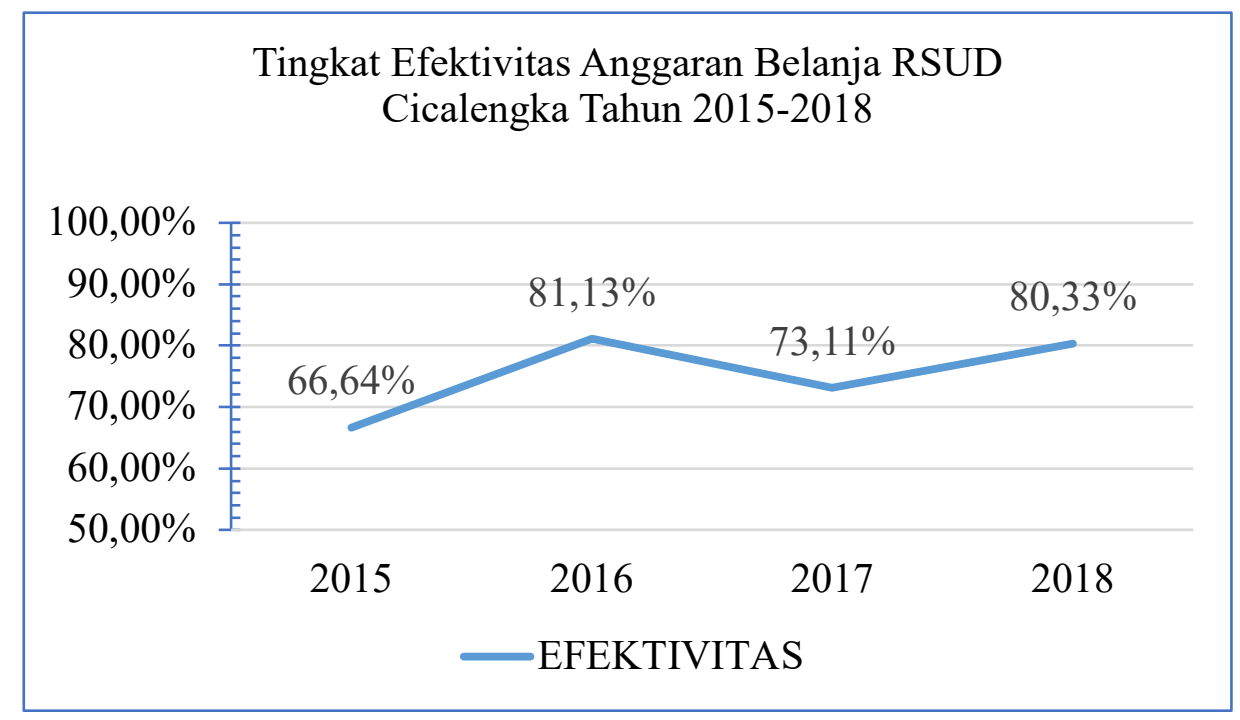

Sumber: Diolah peneliti (2020)

3. Pembahasan Efisiensi dan Efektivtas Anggaran Belanja

Pengukuran hasil efisien anggaran belanja tidak dinyatakan dalam bentuk absolut tetapi dalam bentuk relatif, melihat pengukuran efisiensi anggaran belanja pada tahun 2015-2018 Rumah Sakit Umum Daerah Cicalengka Kabupaten Bandung dikatakan cukup efisien karena disetiap tahunnya mengalami peningkatan dan penurunan yang tidak terlalu signifikan dan cenderung stabil dengan perubahan realisasi anggaran yang naik turun setiap tahunnya. Perubahan tersebut dilihat pada tahun 2015 realisasi anggaran belanja langsung RSUD Cicalengka sebesar Rp.33.117.530.009,- lalu berikutnya pada tahun 2016 mengalami peningkatan sebesar Rp.39.355.161.332,- Pada tahun 2017 realisasi anggaran belanja mengalami penurunan sebesar Rp.36.272.364.685,- lalu berikutnya pada tahun 2018 realisasi anggaran belanja mengalami peningkatan sebesar Rp.46.025.895.602,- walau terjadi kenaikan dan penurunan dalam melaksanakan realisasi anggaran belanja tetapi RSUD Cicalengka tetap melaksanakan optimalisasi efisiensi anggaran.

Berdasarkan hasil observasi efisiensi anggaran belanja di RSUD Cicalengka cukup efisien karena: 1) Mengoptimalisasi penggunaan anggaran belanja dengan melakukan pengarahan bersama pimpinan serta seluruh pegawai di lingkungan RSUD Cicalengka untuk mengutamakan dan memprioritaskan program atau kegiatan yang menjadi kewajiban utama dalam pelayanan pasien 2) Memaksimalkan penggunaan anggaran dari APBD dan BLUD untuk kegiatan pelayanan operasional Rumah Sakit dan mengedepankan kepentingan pelayanan kesehatan kepada masyarakat 3) Melakukan perencanaan anggaran dengan menyusun rencana dimulai dari setiap unit yang ada dirumah sakit hingga pada pembentukan pagu anggaran melalui sistem SIKREN. Sehingga lebih jelas dan terukur dalam penentuan prioritas program dan kegiatan. 
Melihat pengukuran efektivitas anggaran belanja pada tahun 2015-2018 Rumah Sakit Umum Daerah Cicalengka Kabupaten Bandung disetiap tahunnya mengalami peningkatan dan penurunan yang tidak stabil hal itu dapat dilihat dari perkembangan grafik tersebut, pada tahun 2015 efektivitas anggaran belanja berada pada capaian kurang efektif bahkan mendekati angka tidak efektif, berikutnya pada tahun 2016 efektivitas dapat dikatakan cukup efektif dengan peningkatan yang cukup signifikan akan tetapi pada tahun 2017 mengalami penurunan kembali ke capaian kurang efektif dan pada tahun 2018 capaian efektivitas angaran belanja kembali meningkat ke capaian cukup efektif. Perubahan naik turunnya anggaran belanja tersebut dapat dilihat berdasarkan realisasi anggaran belanja dan target anggaran belanja yang dianggarkan RSUD Cicalengka Kabupaten Bandung, pada tahun 2015 target anggaran yang rencanakan adalah Rp.60.464.803.349,- dengan realisasi sebesar Rp.40.291.210.289,- berikutnya pada tahun 2016 target anggaran belanja yang direncanakan mengalami penurunan sebesar Rp.57.938.814.108.- dengan realisasi mengalami peningkatan 47.008.160.261,- pada tahun 2017 menjadi titik balik penurunan tingkat efektivitas dengan target anggaran yang direncanakan Rp.58.678.853.252 dengan realisasi sebesar Rp.44.199.941.446,- namun pada tahun 2018 tingkat efektivitas kembali naik dengan target anggaran belanja lebih tinggi dari tahun sebelumnya yaitu Rp.67.989.176.411,- dengan realisasi belanja yang tinggi pula dari tahun sebelumnya yaitu Rp.54.612.505.791,-

Melihat capaian efektivitas anggaran belanja RSUD Cicalengka Kabupaten Bandung Tahun 2015-2018 berada dibawah angka 95\% dengan rincian pada tahun 2015 terealisasi 66.64\%, Tahun 2016 terealisasi 81.13\%, Tahun 2017 terealisasi $73.11 \%$, dan Tahun 2018 terealisasi $80.33 \%$ dengan rata-rata realisasi seluruhnya adalah $75.30 \%$. Berdasarkan hasil observasi penelitian tidak terealisasinya anggaran belanja karena: 1) Beberapa program dan kegiatan yang direncanakan oleh RSUD Cicalengka belum terlaksana dikarenakan anggaran yang tersedia tidak mencukupi 2) Upaya efisiensi dari pengadaan barang dan jasa dikarenakan keterbatasan anggaran yang tersedia 3) Mengalami kendala dengan pihak ketiga dalam proses pengadaan barang dan jasa sehingga program yang direncanakan tidak terealisasi.

\section{Simpulan}

Tingkat efisensi anggaran belanja pada RSUD Cicalengka Kabupaten Bandung Tahun 2015-2018 berdasarkan hasil perhitungan dan analisis secara keseluruhan dapat dinilai dengan tingkatan cukup efisien sedangkan tingkat efektivitas anggaran belanja pada Tahun 2015-2018 menunjukan hasil secara keseluruhan berada pada tingkatan kurang efektif bahkan mendekati tingkatan tidak efektif. Upaya dalam melaksanakan efisiensi anggaran telah dilakukan oleh RSUD Cicalengka dengan mengoptimalisasi penggunaan anggaran sebaik mungkin dan memaksimalkan penggunaan anggaran yang berasal dari APBD dan BLUD untuk keperluan pelayanan kesehatan kepada masyarakat serta menyusun perencanaan program dari setiap unit dan bidang dengan pemanfaatan sistem informasi SIKREN sehingga lebih jelas dan terukur dalam penentuan prioritas program dan kegiatan. Rendahnya capaian efektivitas anggaran belanja terjadi karena beberapa program dan kegiatan tidak terealisasi sehingga anggaran yang tidak tersedia tidak tercukupi dan mengalami kendala ketika mengadakan proses pengadaan barang dan jasa. 


\section{Referensi}

Ayuningtyas, D. N. (2014). Akutansi Sektor Publik. Jakarta: Salemba Empat.

Halim, A. (2012). Akuntansi Keuangan Daerah. Bandung: Salemba Empat.

Kaunang, C. E., \& Naukoko, A. T. (2016). Analisis Kinerja Pengelolaan Keuangan Daerah Dan Tingkat Kemandirian Daerah Di Era Otonomi Daerah: Studi Pada Kota Manado (Tahun 2010-2014). Jurnal Berkala Ilmiah Efisiensi, 16(2), 355-365.

Khusaini, M. (2018). Keuangan Daerah. Malang: Universitas Brawijaya Press.

Mahmudi, M. (2019). Manajemen Kinerja Sektor Publik. Dalam Akademi Manajemen Perusahaan YKPN, Yogyakarta (3rd Ed., Vol. 1). Yogyakarta: UPP STIM YKPIN.

Mahsun, M. (2014). Konsep Dasar Pengukuran Kinerja.

Nafarin, M. (2012). Penganggaran Rencana Kerja Perusahaan. Edisi Kesatu. Jakarta: Salemba Empat.

Republik Indonesia. 2014. Peraturan Undang-Undang No. 23 Tahun 2014 Tentang Pemerintahan Daerah. Lembaran Negara Republik Indonesia Tahun 2014 Nomor 244. Sekretariat Negara: Jakarta.

Republik Indonesia. 2009. Undang-Undang No. 44 Tahun 2009 Tentang Sumber-Sumber Pendapatan Dan Biaya Rumah Sakit. Lembaran Negara Republik Indonesia Tahun 2009 Nomor 153. Sekretariat Negara: Jakarta

Republik Indonesia. 2015. Peraturan Menteri Keuangan No. 258 Tahun 2015. Tentang Tata Cara Pemberian Penghargaan Dan Pengenaan Sanksi Atas Pelaksanaan Anggaran Belanja Kementrian/Lembaga. Sekretariat Negara: Jakarta

Republik Indonesia. 2018. Peraturan Menteri Dalam Negeri No. 79 Tahun 2018. Tentang Pedoman Teknis Pengelolaan Badan Layanan Umum Daerah. Lembaran Permendagri Nomor 1213. Sekretariat Negara: Jakarta

Republik Indonesia. 1996. Keputusan Kementrian Dalam Negeri Nomor 690. 900-327 Tahun 1996. Tentang Klasifikasi Kriteria Kinerja Keuangan. Sekretariat Negara: Jakarta

Rumah Sakit Umum Daerah Cicalengka. 2020. Laporan Keuangan Tahun 2015. Sekretariat Unit Pelaporan Keuangan: Cicalengka

Rumah Sakit Umum Daerah Cicalengka. 2020. Laporan Keuangan Tahun 2016. Sekretariat Unit Pelaporan Keuangan: Cicalengka

Rumah Sakit Umum Daerah Cicalengka. 2020. Laporan Keuangan Tahun 2017. Sekretariat Unit Pelaporan Keuangan: Cicalengka

Rumah Sakit Umum Daerah Cicalengka. 2020. Laporan Keuangan Tahun 2018. Sekretariat Unit Pelaporan Keuangan: Cicalengka

Shah, A. (2007). Local Government: Public Sector Governance And Accountability Series. Washington: The World Bank.

Sugiyono. (2016). Memahami Penelitian Kualitatif. Bandung: Alfabeta.

Umam, K., \& Ariyoso, D. (2019). Manajemen Kinerja Kementerian Sekretariat Negara Dalam Mengelola Pelayanan Informasi Publik. Ministrate: Jurnal Birokrasi Dan Pemerintahan Daerah, 1(1), 19-38. https://doi.org/10.15575/jbpd.v1i1.6312 